\title{
PENGIMBANGAN SENJATA NUKLIR IRAN MELALUI KEAMANAN KOLEKTIF NEGARA TELUK (GULF COOPERATION COUNCIL)
}

IRAN'S NUCLEAR WEAPON BALANCEMENT THROUGH THE GULF COOPERATION COUNCIL

\author{
Mira Nanda Kurnianta \\ Universitas Airlangga \\ E-mail : miranandakurnianta@gmail.com
}

\begin{abstract}
ABSTRAK
Keamanan akan selalu diupayakan oleh suatu negara untuk mencapai lingkungan yang kondusif baik secara internal maupun eksternal. Begitu pula yang dilakukan oleh negaranegara di Timur Tengah yang membangun kerja sama Gulf Coopertion Council sebagai upaya untuk menghadapi ancaman nuklir Iran. Untuk mecegah Iran sebagai hagemon di kawasan, GCC tidak hanya meningkatkan kerja sama militer antar anggotanya saja. Tetapi GCC juga menggandeng militer Amerika Serikat untuk meningkatkan kualitas militernya. Keamanan kolektif memang sangat diperlukan untuk menghadapi tantangan dari program nuklir Iran sebagai ancaman ketidakstabilan di teluk Arab. Untuk mengkaji lebih lanjut penelitian ini menggunakan metode kualitatif dengan menggunakan sumber data dari berbagai jurnal, buku, maupun dokumen resmi.
\end{abstract}

Kata Kunci : Nuklir, Iran, GCC, Keamanan Kolektif

\begin{abstract}
Security will always be pursued by a country to achieve a conducive environment both internally and externally. The same is true for countries in the Middle East who are building cooperation with the Gulf Cooperation Council as an effort to deal with Iran's nuclear threat. To prevent Iran from becoming a regional hegemon, the GCC does not only increase military cooperation between its members. But the GCC also cooperates with the United States military to improve the quality of its military. Collective security is indeed very necessary to face the challenges of Iran's nuclear program as a threat to instability in the Arab Gulf. To further examine this research using qualitative methods by using data sources from various journals, books, and official documents.
\end{abstract}

Keywords : Nuclear, Iran, GCC, Collective Security 


\section{PENDAHULUAN}

Keamanan merupakan sebuah cita-cita yang ingin dicapai oleh semua negara. Berbagai macam upaya akan dilakukan oleh negara untuk mencapai keamanan baik secara internal maupun eksternalnya. Tidak terkecuali, setiap negara akan bergabung dengan sebuah lembaga internasional, organisasi, dan bekerjasama dengan negara lain untuk mencapai keamanan ditingkat yang lebih besar, yakni tingkat regional. Begitu pun dengan negara-negara di Timur Tengah seperti Bahrain, Kuwait, Oman, Qatar, Saudi Arabia, dan Uni Emirat Arab (UAE) membangun kerjasama untuk meningkatkan kapasitas mereka melalui GCC (Gulf Cooperation Council). GCC membentuk sebuah keamanan kolektif yang bertujuan untuk menghadapi ancaman eksternal, terutama ancaman dari negara tetangga seperti Iran yang berambisius untuk menjadi hagemon di kawasan (Steele, 2011).

Ambisius Iran di kawasan berasal dari revolusi Iran tahun1979 yang sering dilihat sebagai permulaan persaingan antara Iran dengan negara GCC, terutama Arab Saudi. Revolusi Iran tahun 1979 dicirikan sebagai salah satu revolusi paling signifikan dalam sejarah. Hal tersebut dikarenakan mampu mengganti sepenuhnya rezim lama dengan sistem yang berbeda. Ayatollah Ruhollah Khomeini, pemimpin revolusi Iran, percaya bahwa umat Islam secara alami cenderung ke arah pemerintahan Islam (Weddington, 2017). Prinsip-prinsip Islam yang menjadi dasar pemerintahan baru Iran, membuat Iran ingin menerapkan prinsip-prinsip tersebut pada negara-negara tetangganya di kawasan teluk Arab. Ideologi Iran yang readikal tersebut menentang ideologi konservatif Arab Saudi yang menganut sistem monarki. Iran juga menentang hubungan Arab Saudi sebagai negara islam, dengan aliansi barat terutama Amerika.

Iran menganggap Arab Saudi merupakan rival di kawasan. Untuk memperoleh dominasi di wilayah teluk Arab, Iran melihat Arab Saudi sebagai penghambat bagi penyebaran revolusi Iran di negara tetangganya. Hal tersebut dikarenakan Iran bersaing dengan Arab Saudi untuk mendapatkan posisi kepemimpinan komunitas Muslim global karena keduanya merupakan negara yang besar, jika dibandingkan negara lainnya yang masih berada dalam satu kawasan. Oleh karenanya, Iran memiliki program besar untuk meningkatkan kapabilitas negaranya melalui mengembangkan program nuklir Iran. Tentu saja, hal tersebut menjadi sebuah ancaman bagi Arab Saudi dan negara GCC lainnya. Arab Saudi percaya bahwa program nuklir Iran merupakan salah satu ambisi Iran untuk mendominasi kawasan Timur 
Tengah. Dengan adanya senjata nuklir, tentunya Iran mengharapkan kekuatan regional akan bergeser mendukung Iran secara permanen. Iran akan menggunakan senjata tersebut untuk menggertak negara-negara lainnya, serta berharap bahwa negara lain juga akan tunduk pada tuntutan-tuntutan yang diajukan Iran.

Melihat tindakan yang dilakukan Iran tentu menciptakan sebuah insecurity bagi negara-negara tetangganya. Program nuklir Iran tentunya menjadi salah satu tantangan keamanan, politik dan diplomatik di kawasan. Tidak diragukan lagi, program nuklir Iran akan menyebabkan struktur keamanan menjadi goyah. Nuklir Iran mungkin akan semakin menyulitkan orientasi geopolitis yang sudah rumit di Timur Tengah, yang sejarahnya telah banyak membawa Timur Tengah pada konflik, dan ketidakpercayaan. Menurut Ehteshami (2010) program nuklir Iran telah menyebabkan ancaman serius di antara negara-negara teluk Arab Gulf Cooperation Council (Jamal, 2014).

\subsection{Rumusan Masalah}

Melihat kondisi Iran yang memiliki program nuklir di negaranya dan dianggap menjadi sebuah ancaman bagi negara-negara tetangganya, maka muncullah sebuah rumusan masalah dalam penelitian ini "Bagaimana negara GCC menanggapi realitas nuklir Iran supaya Iran tidak menjadi hagemon di tingkat regional?"

\section{TINJAUAN LITERATUR}

\subsection{Teori Neoliberal Institusionalisme}

Pandangan neoliberal institusionalisme dalam sebuah hubungan internasional menekankan bahwa suatu negara memerlukan adanya kerja sama dengan negara lain. Neoliberal institusionalisme lebih memntingkan efisiendi dari pada harus berfokus pada kekuasaan sebagai instrument (Jervis, 1999). Argumen yang diutarakan dalam neoliberal institusionalisme yang biasanya secara implisit, mengatakan bahwa distribusi konflik dapat menjadi sebuah potensi keuntungan bersama yang memiliki manfaat timbal balik yang besar. Tentunya jika konflik tersebut dapat diatasi dengan nilai-nilai saling melindungi, bukan dengan suatu perselisihan.

Menurut Sigal (1998) neoliberal institusionalisme percaya bahwa pengaturan sebuah kebijakan yang cerdik dalam berbagai macam hal akan menjadi sebuah nilai yang positif. Hal 
ini dilandasi karena dunia dipenuhi dengan rasa kecemasan dan ketidakpercayaan. Oleh karenanya pengaturan supaya dunia menjadi lebih baik diperlukan. Maka tidaklah heran jika neoliberal institusionalisme ini sangat menekankan peran dari sebuah institusi. Peran institusi tersebut secara luas dapat didefinisikan sebagai pola yang mampu mempertahankan perilaku bersama setelah menerima persetujuan secara formal. Seperti yang dikatakan oleh Charles Glaser (1994) institusi adalah produk dari adanya suatu kesamaan faktor, seperti misalnya adanya kepentingan negara atau kendala, yang kemudian secara sistem dapat memengaruhi apakah negara tersebut harus bekerja sama. Sehingga pada intinya, dapat dikatakan bahwa neoliberal berpikir mendirikan sebuah institusi dapat meningkatkan suatu hubungan kerja sama (Jervis, 1999).

\subsection{Konsep Keamanan Kolektif (Collective Security)}

Keamanan kolektif atau collective security merupakan bentuk pengaturan keamanan antarnegara. Keamanan kolektif menekankan bahwa suatu negara memerlukan kerjasama dengan negara lain. Istilah sederhananya, keamanan kolektif yakni upaya sekelompok negara untuk bertindak bersama untuk menjaga keamanan. Untuk menjaga keamanannya, negaranegara tersebut harus berkomitmen untuk membantu pertahanan anggotanya dalam merespon aggresor atau musuh. Keamanan kolektif bertujuan untuk membuat efek gentar atau detterent effect dengan cara meyakinkan kepada aggresor bahwa agresor tersebut akan menghadapi pasukan sekutu dalam jumlah yang besar (Pratama \& Candra, 2014). Menurut Aleksovski, Bakreski, dan Avramovska mengatakan bahwa dalam sistem keamanan kolektif, musuh adalah ancaman bagi perdamaian dan keamanan regional atau internasional.

Terdapat lima asumsi dasar dalam keamanan kolektif. Lima asumsi tersebut sepeti yang dijelaskan oleh Olganski yakni pertama, dalam konflik bersenjata, negara anggota menyepakati negara mana yang tergolong musuh (aggressor). Keuda, semua negara anggota bersama membendung atau mencegah agresi dimana pun sumber atau asalnya. Ketiga, semua negara anggota memiliki kebebasan bertindak untuk bergabung melawan musuh. Keempat, gabungan kekuasaan anggota cukup untuk melawan musuh. Kelima, keamanan kolektif dapat membuat negara musuh dikalahkan (Irwan, 2017).

Keamanan kolektif adalah desain untuk memberikan kepastian terhadap tindakan kolektif antarnegara. Keamanan kolektif merupakan salah satu metode manajemen daya dalam 
sistem internasional. Tujuan dari keamanan kolektif yakni berusaha untuk mengelola security dilemma yang diakibatkan adanya sebuah pengaturan keamanan suatu Negara, yang dapat menyebabkan ancaman keamanan negara lain (Bassiouni, 2000). Sehingga, ancaman tersebut dapat terkoordinasi oleh komunitas atau institusi internasional secara kolektif. Sistem keamanan kolektif dirancang sebagai perbaikan atas keseimbangan sistem kekuasaan yang tidak pasti, tidak memadai dan tidak realistis dalam pengelolaan keamanan internasional. Dalam keseimbangan sistem kekuasaan, perdamaian dan stabilitas internasional dihasilkan dari penyeimbangan kekuatan relatif di antara kekuatan-kekuatan utama sistem internasional. Maka dari itu, teerciptalah sebuah mekanisme baru yang dikenal sebagai keamanan kolektif untuk memperbaiki tanggung jawab dan pemeliharaan perdamaian internasional setiap negara dalam sistem internasional.

Negara anggota dari keamanan kolektif harus bertanggung jawab jika ada agresi di salah satu negara anggota. Semua negara bersatu dan secara kolektif menolak agresi tersebut. Semua Negara, baik besar atau kecil, bertanggung jawab untuk menjaga perdamaian. Dengan demikian, prinsip yang mendasari sistem keamanan kolektif adalah semua untuk satu dan satu untuk semua. Sehingga, semua dukungan dari negara anggota cukup untuk mencegah tindakan agresif oleh musuh bersama. Menurut George Schwarzenberger dalam Bassiouni (2000) keamanan kolektif dapat didefinisikan sebagai sebuah mesin untuk mencegah atau melawan serangan apa pun terhadap tatanan internasional yang sudah mapan. Sementara Hans Morgenthau dalam Bassiouni (2000) mendefinisikan keamanan kolektif sebagai sistem kerja keamanan kolektif yang harus dijaga oleh persenjataan dan unsur-unsur kekuatan nasional lainnya. Keamanan menjadi perhatian semua bangsa, seolah-olah keamanan negara sendiri dipertaruhkan.

Negara memainkan peran penting dalam keamanan kolektif. Dalam keseimbangan sistem kekuasaan, negara tetap sebagai aktor utama dalam mengambil tindakan, termasuk aksi militer. Tidak hanya dalam pertahanan diri saja, tetapi negara juga akan melakukan tindakan militer ketika kepentingan vitalnya terancam. Keamanan kolektif adalah tempat keamanan dari setiap negara anggota yang secara keseluruhan dijamin oleh tindakan bersama, berdasarkan aturan dan metode yang ditentukan (Bassiouni, 2000). 


\section{METODOLOGI PENELITIAN}

Berdasarkan penjelasan singkat di atas, penelitian ini mengunakan metode penelitian kualitatif. Pembahasan dalam penelitian ini akan disampaikan secara deskriptif dengan menggunakan kata-kata ataupun kalimat. Hasil penelitian tersebut diperoleh berdasarkan analisis logis terhadap bukti-bukti dan data-data yang digunakan. Adapun yang menjadi sumber data yang digunakan dalam penelitian ini yaitu menggunakan data sekunder yang diperoleh melalui buku dan jurnal ilmiah para akademisi ataupun praktisi, data-data yang berasal dari website resmi pemerintah ataupun organisasi tertentu, jurnal berita yang diperoleh dari media massa, serta data-data yang diperoleh dari dokumen-dokumen tertentu yang relevan untuk melengkapi penelitian ini. Dengan kata lain penelitian ini tidak melakukan observasi secara langsung ke lapangan dan juga tidak melakukan komunikasi dengan pihak tertentu yang berada di objek penelitian.

\section{HASIL DAN PEMBAHASAN}

\subsection{Respon GCC Dalam Menghadapi Senjata Nuklir Iran}

Iran merupakan negara yang sedang mengembangkan senjata nuklirnya sebagai bentuk dari pertahanan dirinya atau self-help. Pada awalnya, setelah revolusi islam tahun 1979, Iran semakin mengembangkan tenaga nuklirnya yang mereka klaim sebagai tenaga pembangkit listrik di negaranya. Namun kenyataannya, badan rahasia Amerika Serikat mengatakan bahwa Iran belum memerlukan nuklir untuk menggantikan listriknya. Negaranegara barat pun mulai menaruh kecurigaan pada pengembangan nuklir di Iran yang bertujuan untuk menciptakan bom atom. Pada tahun 2003, Badan Energi Atom Internasional menyatakan bahwa pabrik uranium berkadar tinggi ditemukan di Iran (CNN Indonesia, 2014).

Meskipun dicurigai oleh negara-negara lain, Iran tetap menegaskan bahwa program pengembangan nuklirnya tidak membahayakan negara manapun. Melalui juru bicara kementrian luar negeri Iran, Bahram Ghasemi mengatakan bahwa pengembangan nuklir Iran tidak mengancam negara manapun. Tehran hanya mengambil kebijakan untuk memperkuat kemampuan pertahannya untuk mencegah niat buruk lawannya yang ingin menginvasi Iran. Iran bertujuan menggunakan kekuatannya untuk mengatasi permasalahan yang mengganggu 
stabilitas keamanan di kawasan. Bukan untuk mengancam negara-negara yang lain (ParsToday, 2018).

Melihat Iran yang gencar dengan program pengembangan nuklirnya, hal tersebut membuat negara-negara tetangga Iran merasa terancam. Iran dianggap berambisi untuk menjadi hegemonik regional yang dapat memunculkan dilemma keamanan baru. Meskipun Iran mengklaim bahwa program nuklirnya tidak berbahaya, tetapi tetap saja kegiatan Iran tersebut merupakan ancaman tingkat negara yang paling signifikan terhadap keamanan di kawasan Teluk Arab (Arabian Gulf).

Ketidakpastian program nuklir Iran banyak memunculkan kecurigaan. Sebagai negara yang pernah bersitegang dengan Iran, tentunya Arab Saudi memiliki kekhawatiran tersendiri. Arab saudi takut bahwa motivasi sesungguhnya dibalik berkembangnya program nuklir Iran yakni akan menjadi sebuah bom pada suatu hari nanti. Arab Saudi memandang program Iran sebagai bagian dari upaya Iran untuk menjadi kekuatan dominan di kawasan. Menurut Fahad M. Alsultan dan Pedram Saeid dalam Weddington (2017) nuklir Iran akan menjadi mimpi buruk bagi Arab Saudi. Bahkan kemampuan senjata nuklir Iran akan mengubah keseimbangan kekuasaan regional. Menanggapi program nuklir Iran, Arab Saudi sebagai salah satu negara besar di kawasan teluk Arab menjadi lebih gencar untuk mempertahankan keseimbangan kekuasaan di wilayah tersebut. Salah satu langkah yang diambil Arab Saudi sebagai negara penggagas (pioneer) dari GCC yaitu dengan cara meningkatkan kerjasama antarnegara anggota GCC. Negara-negara GCC juga sangat tidak mempercayai Iran, sehingga secara bersama-sama negara GCC membahas isu-isu militer seperti pertahanan bersama, pangkalan militer, serta mendukung satu sama lain terhadap kemungkinan-kemungkinan yang terjadi dalam pengembangan nuklir Iran.

Pada level negara, negara-negara yang tergabung dalam GCC menganalisa pentingnya membangun kekuatan militer yang efektif untuk menghadapi ancaman Iran. Karakterisitik utama dalam kerjasama GCC yakni mengembangkan kekuatan yang ditujukan untuk membangun pertahanan negara dari ancaman eksternal. Salah satu dari beberapa opsi yang tersedia untuk negara-negara GCC dalam menghadapi nuklir Iran yaitu menambah kepemilikan senjata militer canggih mereka. Termasuk juga senjata yang paling ofensif seperti rudal jelajah, pesawat modern, serta bom berpanduan presisi. Dengan memperkuat kekuatan militer mereka, negara-negara GCC ini dapat mengurangi risiko bagi diri mereka sendiri dan 
kelompok jika Iran melakukan tindakan agresi. Dengan demikian, hal tersebut dapat memperkuat posisi negara GCC dalam kawasan sehingga Iran tidak dapat meningkatkan pengaruh negaranya di tingkat regional. Bahkan, dapat dibayangkan bahwa Iran akan menghadapi perimbangan kekuatan dari perubahan signifikan pada senjata dan kekuatan militer negara tetangganya (Weddington, 2017).

Oleh karenanya, negara GCC memodernisasi persenjatan militernya yang menghabiskan banyak biaya. GCC menghabiskan dana sebesar 720 juta USD untuk membeli senjata modern dari Amerika, Perancis, dan Inggris (Steele, 2011). Mengingat ketidakpastian geopolitik dari ancaman nuklir Iran, pemerintah GCC akan terus membelanjakan banyak uang untuk pertahanan. Untuk mencapai sistem pertahanan yang maksimal, negara GCC mengkoordinasi dan menjadikan pembelian senjata militer sebagai investasi. Investasi persenjataan militer tersebut digunakan untuk pertahanan udara, laut, dan darat. Selain untuk meningkatkan kapabilitas militernya, pembelian senjata yang modern juga dianggap dapat memberikan prestise dalam status regional.

\subsection{Kerja Sama Militer GCC Dengan Militer Amerika Serikat}

Selain memodernisasi persenjatannya, negara GCC juga melakukan kerjasama dengan Amerika. Kerjasama tersebut terbagi dalam lingkup pembelian senjata militer serta pelatihan militer. Kerjasama militer yang dilakukan GCC dengan Amerika dikarenakan Amerika dianggap mampu melindungi GCC dengan kekuatannya. Terlebih Amerika menyediakan senjata canggih untuk keperluan modernisasi persenjatan GCC. Untuk melawan kemungkinan terjadinya ketidakstabilan di kawasan, Amerika Serikat telah setuju untuk menjual sejumlah besar senjata-senjata militer ke negara-negara GCC, termasuk senjatasenjata ofensif besar seperti pesawat tempur canggih dan bom berpemandu satelit.

Menurut U.S Congressional Research Service (CRS), kerjasama jual-beli persenjataan antara GCC dengan Amerika Serikat mencapai kesepakatan untuk menjual senjata ke Arab Saudi, Uni Emirat Arab (UEA), Kuwait, dan negara GCC lainnya. Penjualan yang disepakati dan diusulkan ini termasuk delapan puluh empat pesawat tempur/penyerang F-15SA ke Arab Saudi, lima ratus AIM-120C-7 Advanced Medium Range Air-to-Air Missiles (AMRAAM) ke Arab Saudi, seribu GBU-31B V3 Joint Direct Attack Munitions (JDAM) (2.000 lb) ke Arab Saudi, Tujuh puluh AH-64D APACHE serang helikopter ke Arab Saudi, 
seratus Sistem Angkatan Darat Taktis Angkatan Darat (ATACMS) ke UAE, Enam puluh AH64D APACHE serang helikopter ke UEA, peningkatan unit bom terpandu ke UAE, dua puluh lima AIM-120C-7 AMRAAM ke Bahrain, tiga puluh ATACMS T2K Rudal Kesatuan ke Bahrain, AIM-120C-7 AMRAAM ke Kuwait, delapan belas pesawat F-16 Block 50/52 ke Oman (Rosenfield, 2012).

Pembelian persenjataan canggih ke Amerika diharapkan dapat menjadi sebuah antisipasi dari serangan Iran ke negara GCC. Contohnya, rudal jelajah udara Storm Shadow yang dikirim ke Arab Saudi dan UAE akan memungkinkan negara-negara ini menyerang fasilitas ekonomi penting Iran di Teluk tanpa mengirim pasukan militer formasi besar. Penyerangan pesawat tempur berpotensi melakukan pertempuran dengan Iran di udara. Rudal Storm Shadow bisa diluncurkan dari atas Arab Saudi atau UEA ke wilayah Iran dengan tujuan untuk merusak fasilitas penting di Iran. Kemudian misil rudal ATACMS T2K yang dikirim ke Bahrain dan UEA merupakan sistem artileri dengan kisaran jarak ledakan sejauh 270 atau 300 kilometer, menggunakan panduan berbantuan GPS dengan ledakan seberat 550 pon (Rosenfield, 2012).

Selain kerjasama pembelian senjata, GCC juga menjalani pelatihan militer dengan Amerika yakmi U.S Central Command (USCENTCOM). Kerjasama tersebut tergabung dalam program yang bernama Theater Security Cooperation (TSC). Banyak program dan kegiatan yang dilakukan oleh negara GCC dengan USCENTCOM.. Melalui kegiatan TSC, GCC dan USCENTCOM melakukan latihan dan pelatihan multinasional, memberikan bantuan keamanan melalui Foreign Military Sales (FMS), Pelatihan dan Pendidikan Militer Internasional (IMET), serta pertukaran militer-ke-militer. Kegiatan TSC antar GCC dengan USCENTCOM didasarkan pada kerja sama yang berdasarkan pada kepentingan bersama. Terdapat empat bidang yang menjadi fokus kerjasama tersebut yakni training, exchanges, equipping and exercises.

Rencana TSC yang efektif dapat menjadi sebuah latihan untuk mendukung tujuan nasional negara GCC di tingkat regional. Komandan USCENTCOM, Jenderal David Patraeus (2009) mengatakan bahwa dalam pelatihan militer juga akan dilaksanakan diskusi yang akan membahas secara rinci isu-isu terkini yang mempengaruhi wilayah GCC, bagaimana penanganannya, serta cara paling efektif apakah yang akan digunakan untuk menghadapinya (Baggett, 2010). Perencana USCENTCOM mencoba mengembangkan model baru 
berdasarkan penguatan hubungan yang ada dan membangun kemitraan regional antarnegara GCC guna menyediakan keamanan kolektif untuk menciptakan kondisi damai di wilayah Teluk Arab.

Sebagai bentuk kerjasama yang matang di kawasan Teluk Arab, dukungan dari USCENTCOM kepada GCC tentunya akan membuat GCC meeningkatkan kemampuan aksi militernya. Menurut USCENTCOM, GCC memiliki kemampuan diplomatik, ekonomi, dan militer yang diperlukan untuk membentuk keamanan regional yang komprehensif. Tujuan dari TSC adalah untuk mencegah agresi dan menyelesaikan konflik sembari mempertahankan kedaulatan wilayah. Sehingga negara GCC diharapkan dapat mencegah atau menyelesaikan permasalahan-permasalahan yang uncul di kawasan, seperti menangani permasalahan nuklir Iran (Baggett, 2010).

Menindaklanjuti dari kerjasama militer, GCC dan USCENTCOM juga melakukan latihan multi-perang di Semenanjung Arab di Kuwait. Latihan tersebut disebut sebagai Eagle Resolve. Latihan ini melibatkan hampir 3.000 tentara Amerika yang mewakili markas Komando Pusat USCENTCOM. Pelatihan ini disimulasikan dan dirancang untuk memvalidasi kemampuan taktis darat, maritim dan pasukan udara tiap negara anggota GCC (Cordesman, 2016). Eagle Resolve adalah pelatihan multinasional yang dirancang untuk mendukung pertahanan negara GCC. Fokus pelatihan dari Eagle Resolve yakni pertahanan udara, manajemen pertahanan, perlindungan infrastruktur yang vital, pertahanan nuklir pasif, dan keamanan perbatasan. Latihan Eagle Resolve menunjukkan dedikasi dari komando pusat AS kepada mitra regional GCC.

Eagle Resolve menjadi latihan utama USCENTCOM dengan negara-negara anggota GCC. Menurut Mayor Jenderal Robert Catalanotti, direktur pelatihan USCENTCOM mengatakan bahwa pelatihan Eagle Resolve dirancang untuk menantang pasukan militer Amerika dan GCC dalam berbagai disiplin ilmu di udara, di darat dan di laut. Tujuan pelatihan tersebut adalah membangun hubungan dan kemampuan yang akan menyatukan kekuatan militer negara anggota GCC dan meningkatkan stabilitas kawasan. Latihan seperti Eagle Resolve juga memungkinkan negara GCC untuk melihat peluang dan belajar bagaimana Amerika menjalankan operasi militer, serta berkontribusi dalam mempromosikan perdamaian jangka panjang di kawasan. Eagle Resolve juga memberikan kekuatan multilateral dengan peluang memperluas tingkat kerjasama. Terdapat sekitar 2.000 personel militer Amerika yang 
berpartisipasi dalam latihan Eagle Resolve ini. Semuanya tergabung dalam pasukan angkatan udara, angkatan laut, serta korps marinir (US Central Command, 2013).

\subsection{Keseimbangan Kekuatan (Balance of Power) Militer Iran Dan GCC}

Balance of power sering didefinisikan sebagai interaksi antarnegara yang menjamin kelangsungan hidup dari sebuah sistem yang dapat mencegah munculnya dominasi atau hagemoni suatu negara. Hadley BULL (1965) menjelaskan bahwa fungsi dari balance of power yaitu sebagai perimbangan kekuasaan dalam masyarakat internasional. Hal tersebut bertujuan untuk menjaga perdamaian sekaligus mempertahankan kemerdekaan dan kedaulatan negara dari ancaman dominasi dalam satu kawasan (Jerotijevic \& Palevic, 2016). Maka dari itu, sangat diperlukan negara penyeimbang terhadap suatu kekuatan berlebih atau dominan. Negara penyeimbang yang dimaksud yaitu baik satu negara atau negara yang tergabung dalam kelompok. Sesuai dengan tujuan dan fungsinya, keinginan suatu negara untuk meningkatkan kekuatannya yaitu dikarenakan ingin mencapai suatu keseimbangan.

Bagitu pula halnya dengan negara GCC. Untuk mencegah Iran menjadi dominasi kawasan melalui kekuatan nuklirnya, maka negara anggota GCC pun juga melakukan berbagai upaya untuk menyeimbangkan kekuatan yang dimiliki Iran.

\section{KESIMPULAN}

Meningkatkan kekuatan militer tentunya menjadi suatu hal yang penting jika terdapat satu kekuatan berlebih dalam satu kawasan. Berbagai macam upaya dilakukan untuk mencegah munculnya satu dominasi yang dapat mengancam stabilitas kawasan. Hal tersebut yang dilakukan oleh negara Gulf Cooperation Council atau GCC sebagai respon dari pengembangan nuklir Iran. Negara GCC meningkatkan kapabilitas militernya melalui modernisasi persenjataan yang dibeli dari negara-negara besar seperti Amerika, Inggris, dan Perancis. Modernisasi persenjatan juga ditujukan sebagai bentuk investasi dan prestige negara GCC di kawasan teluk Arab. Selain itu, negara GCC juga melakukan pelatihan militer bersama dengan USCENTCOM melalui program TSC (Theater Security Cooperation). Sebagai tindak lanjut kerjasama dengan USCENTCOM, negara GCC juga melakukan pelatihan yang bernama Eagle Resolve untuk menggabungkan kekuatan militer dan 
menciptakan stabilitas di kawasan. Maka dari itu, keamanan kolektif memang sangat diperlukan untuk menghadapi tantangan dari program nuklir Iran sebagai ancaman ketidakstabilan di teluk Arab.

\section{DAFTAR PUSTAKA}

[1] Baggett, J. A. (2010). Way Ahead: CENTCOM's New Strategy for Theater Security Cooperation. Naval War College.

[2] Bassiouni, M. C. (2000). Collective Security and Crime of Aggression. International Criminal law.

[3] BBC Indonesia. (2016, Januari 5). Tujuh hal tentang permusuhan Iran dan Arab Saudi. Retrieved September 21, 2018, from BBC News Indonesia: https://www.bbc.com/indonesia/dunia/2016/01/160105_dunia_iransaudi_musuh

[4] Beck, M. (2015, May 22). Upgrading The Arab League by Establishing a Joint Military Force? Retrieved October 2018, 10, from E-International Relations: https://www.eir.info/2015/05/22/upgrading-the-arab-league-by-establishing-a-joint-military-force/

[5] CNN Indonesia. (2014, September 22). 10 Fakta Mengenai Nuklir Iran. Retrieved September 21, 2018, from Indonesia: https://www.cnnindonesia.com/internasional/20140922155915-120-3985/10-faktamengenai-nuklir-iran

[6] Cordesman, A. H. (2016). Iran and The Gulf Military Balance. Washington: Center For Stratgeic \& International Studies.

[7] Irwan, M. N. (2017). TRANSFORMASI KEBIJAKAN NATO (NORTH ATLANTIC TREATY ORGANIZATION) DALAM PENANGANAN ANCAMAN NON-TRADISIONAL. Makasar: Universitas Hasanudin.

[8] Jamal, U. (2014, September 4). The Iranian Nuclear Programme: Impact on Regional Stability and Security. Retrieved September 21, 2018, from E-International Relations Student: https://www.e-ir.info/2014/09/04/the-iranian-nuclear-programme-impact-onregional-stability-and-security/

[9] Jerotijevic, Z., \& Palevic, M. (2016). THE BALANCE OF POWER - THE SECURITY CONCEPT OF THE INTERNATIONAL COMMUNITY. Ekohomnka vol.62.

[10] Jervis, R. 1999. Realism, Neoliberalism, and Cooperation. International Security Vol.24 No.1.

[11] ParsToday. (2018, Juli 8). Kekuatan Rudal, Garis Merah Iran. Retrieved September 24, 2018, from ParsToday: http://parstoday.com/id/news/iran-i59673kekuatan_rudal_garis_merah_iran 
[12] Pratama, C. P., \& Candra, D. S. (2014). PERKEMBANGAN FIVE POWER DEFENCE ARRANGEMENTS DALAM MENANGGAPI DINAMIKA KEAMANAN ASIA TENGGARA PASCA PERANG DINGIN. Global Vol.16 No.1.

[13] Rosenfield, D. K. (2012). Countering Iran with Arms Sales to the Gulf Cooperation Council States. Institute For Deense Analyses.

[14] Sigal, V. L. (1998). Disarming Stranger: Nuclear Diplomacy with North Korea. Princeton, N.J.: Princeton University Press.

[15] Steele, A. T. (2011). Mirage or Reality: Enabling Gulf Cooperation Council (GCC) Collective Defense. Washington: Naval War College.

[16] US Central Command. (2013, May 2). U.S GCC Nation begin defense excercise. Retrieved October 10, 2018, from The Fort Campbell Courier: http://fortcampbellcourier.com/news/article_87687332-b36e-11e2-b30d0019bb2963f4.html

[17] Weddington, D. (2017). Rivalry in the Middle East: The History of Saudi-Iranian Relations and its Implications on American Foreign Policy. Missouri: BearWorks Institutional Repository. 